\title{
The Flat Tax and Efficiency of Fiscal System
}

\author{
Marsida Harremi \\ University "Fan S. Noli", Korce, Albania \\ Department of Finance \\ E-mail:mharremi@yahoo.com
}

\section{Doi:10.5901/ajis.2013.v2n8p446}

\begin{abstract}
What has been the impact of the flat tax in the efficiency of the fiscal system? To analyze these effects we are taking into consideration fourteen ex communist countries which have performed reforms after the year 2001. These countries have supported the flat tax application and therefore have undermined the tax level. To make this comparison we have obtained from a database of the World Bank "Paying Taxes" which ranks fiscal systems for 185 different countries according to their efficiency. By order of the data in the database of places to consider for a period of 5 years (2008-2012), it has been concluded that the flat tax has not improved the efficacy of the fiscal system. Excluding some countries, the efficiency of the fiscal system after the flat tax reform, has remained the same, even in any country are feeling the negative effects of the flat tax. It is recommended that countries ex - communist renounce flat tax and fiscal legislation adopted by developed countries to apply progressive tax.
\end{abstract}

Keywords: Efficience; fiscal system; flat tax; ex-communist countries

\section{Introduction}

The discussion around the flat tax is one of the most open debates among economists. The flat tax characterizes the simplicity of the fiscal system, a principle embraced by the great economist, Adam Smith. According to Smith, this fiscal system is efficient, clear and convenient. These types a flat tax concepts demonstrate the general themes of classical liberalism (Evans, Anthony J). The flat tax, later defined by Hall and Rabushka, is a cash-flow business tax rate plus wage at same rate. The flat fee is based on the principle that all income is taxed only once during single turnover and this time it is in this moment of their tenure.

Although there were early experiences of the flat tax such as Jersey in the 1940s, Hong Kong in 1947, the concept of the flat tax known today took its shape in 1994. During that the tax was adopted by the Baltic countries (Estonia, Lithuania, Latvia). Debate became even more interesting when it was adopted from Russia in 2001. After this event, several former communist countries began to apply flat tax as well.

\section{Advantages of the flat tax}

The flat tax progressive taxation differs from the way of taxation. Labor and capital are not taxed progressively but equal to a percentage. The higher the income from labor the capital will result to a higher tax. Also the percentage remains the same for each level of income from labor and capital gains.

One of the main advantages of the flat tax is that it brings reforms and simplification to the fiscal system. The system simplifies the deployment of an equal tax rate for all income by removing all exceptions, and also there are no brackets for calculating all the different levels of income. Actions and time spent on tax calculations are reduced to maximum. We developed countries simplified tax statements in several pages in a simple statement on the size of a postcard (Forbes 2005).

Equality from the flat tax comes from setting an equal tax rate for all. Percentages of taxes placed lower than the actual percentage despite the low level of tax, and the income level of the budget can be increased. Theoretically a low level of tax increases the desire to pay taxes (E. Hall Rabushka A 2007).

Despite what politicians decide as to who will pay more or less, or who will be penalized or favored, the flat tax has a single objective and benchmark. No matter how much income we get, what kind of business we have, percentage of tax will be the same for all. 
Flat tax reduces tax avoidance and evasion. A simple tax system reduces the scope for legal tax avoidance, by removing many deductions, thresholds and anomalies on which most loopholes are based. It also makes enforcement of taxes easier, reducing the possibility of tax evasion. In addition replacing a system of higher rate taxes with a single, low, flat tax rate reduces the motivation for avoidance.

Income tax is a great disincentive to investing, because it not only has to be profitable enough to cover the tax and also to give a return for the investor. It is also a disadvantage to business start-ups and expansions because the tax system is usually more willing to tax profits than to give relief for losses. Increase income of a country by increasing foreign and domestic investments will bring growth and social welfare.

\section{Theoretical and practical criticism of the flat tax}

At first sight it seems a simple fiscal system, but its implementation in practice is always complex. According to the theory of the flat tax is difficult to implement in practice, especially in developing countries because the economic system itself is complex. Simplification of the system as a whole can be achieved through various other reforms of the flat tax (Weinsbach, DA (2000). This is because of the flat tax simplification is not necessarily linked to the flat tax (Marstin, D. 2005)

Essentially flat tax is regressive. The poor pay proportionately more than the rich, and so undermine the Social Democratic Principle of Richer Helping poorer citizens for the public good. Most of the financial resources owned by the rich, and such inequity is recognized and resented.

The flat tax conducts to an unhealthy fiscal competition among different states. This phenomenon amplifies the migration of the capital and work force. This disadvantage can be eliminated by adopting some harmonization procedures which become absolutely necessary.

The transition to a new system can be complex and costly to begin with, leading to a period of confusion. The ability to discover new means of evasion will always be present, especially during the changeover. They are also inflexible, unlike income taxes where 'fiscal drag' and 'fiscal boots' act as automatic stabilizers in boom and bust periods respectively (Rose Jacqueline).

Other authors go even further, challenging the ideological basis of the flat tax. The flat tax idea was seen as damaging to the democracy. It is possible to have a flat tax, or to have democracy, but not both (Hettich and Winer 1999). Several authors have reached the conclusion that "flat tax is effectively an attack on the entire social structure in which we live" (Murphy 2006). As is seen as theoretical basis, ideological and practical are controversial. Possible reason is that the arguments for the flat tax based more on rhetoric than on analysis and evidence (M. Keen 2006). There are a lot of good reasons why the country should adopt a flat tax (A. Peichl 2006).

\section{Flat tax in developing countries and former communist countries}

While in Western Europe continue to debate about flat tax reform, this reform is now a a reality for most ex - communist countries and several developing countries. The first were the Baltic countries, Estonia in 1994 was followed by Lithuania in Latvia 1994 and 1995. Adoption of the flat tax was adopted by other countries after adoption by the Russian Federation in 2001. Since that year back, almost every time, ex-communist country is part of the list of the flat tax.

Exhibit 1. List of countries that have adopted flat tax to year 2012

\begin{tabular}{|c|l|c|c|c|c|}
\hline No. & Countries & Year of reforme & Ex-communist & Income tax \% & Profit tax \% \\
\hline 1 & Jersey & 1940 & No & 20 & 20 \\
2 & Hong Kong & 1947 & No & 16 & 17.5 \\
3 & Guernsey & 1960 & No & 20 & 20 \\
4 & Jamaica & 1986 & No & 25 & 33.3 \\
5 & Tuvalu & 1992 & No & 30 & 30 \\
6 & Estonia & 1994 & Yes & 21 & 21 \\
7 & Lithuania & 1994 & Yes & 15 & 15 \\
8 & Latvia & 1995 & Yes & 26 & 15 \\
9 & Russia & 2001 & Yes & 13 & 24 \\
10 & Serbia & 2003 & Yes & 19 & 19 \\
11 & Iraq & 2004 & No & 15 & 15 \\
12 & Slovakia & 2004 & Yes & 19 & 19 \\
\hline
\end{tabular}




\begin{tabular}{|l|l|c|c|c|c|}
\hline 13 & Ukraine & 2004 & Yes & 15 & 25 \\
14 & Georgia & 2005 & Yes & 20 & 20 \\
15 & Romania & 2005 & Yes & 16 & 16 \\
16 & Turkmenistan & 2005 & Yes & 10 & 20 \\
17 & Kyrgyzstan & 2006 & Yes & 10 & 10 \\
18 & Pridnestrovie & 2006 & Yes & 10 & 10 \\
19 & Trinidad and Tobago & 2006 & No & 25 & 25 \\
20 & Kazakhstan & 2007 & Yes & 10 & 15 \\
21 & Mongolia & 2007 & Yes & 10 & 10 \\
22 & Macedonia & 2007 & Yes & 9 & 10 \\
23 & Montenegro & 2007 & Yes & 10 & 9 \\
24 & Albania & 2007 & No & 15 & 10 \\
25 & Mauritius & 2007 & Yes & 15 & 10 \\
26 & Czech Republic & 2008 & No & 10 & 10 \\
27 & Bulgaria & 2008 & No & 25 & 10 \\
28 & East Timor & 2008 & Yes & 10 & 25 \\
29 & Belize & 2009 & Yes & 12 & 10 \\
30 & Bosnia Herzegovina & 2009 & Yes & 15 & 24 \\
31 & Belarus & Yes & 10 & 35 \\
32 & Seishele islands & 2009 & Yes & 16 & 10 \\
33 & Paraguay & 2010 & & & 10 \\
34 & Hungary & 2010 & 2011 & & \\
\hline
\end{tabular}

First of all states that are listed in the table, two thirds of the countries that have done the flat tax reform are former communist countries and 9 small or very small islands. So with the exception of Iraq and Paraguay, the flat tax reform is carried out either in the former communist countries or micro-states. Secondly, the number of ex-communist countries that have adopted the flat tax reform before 2001 were 8, after 2001, the number of countries that have adopted flat tax almost quadrupled. It seems that the reform in Russia has been the main driver for the performance of this reform. Before we turn into democracies, these countries not had a genuine tax system and social protection (Aslund, A. 2007). This fact shows that they were in very good conditions to carry out this reform than developed countries. Consequently, these countries appear to have been perfect candidates for flat tax experiment (JM Ellis 2011).

Even within the group of former communist countries has changed. Countries that have adopted flat tax before 2001, have had a very high tax level. While countries that have performed reform after 2001 are characterized by much lower levels than before the reform levels, less than 20\% (Keen, M. 2006).

There is a simple reason for the flat tax reform adopted by the former communist countries. These countries are generally much smaller than the application of progressive tax will punish you more. Also these countries have a higher administrative Takes and adoption of the flat tax effectively brings.

\section{The flat tax and the effectiveness of the fiscal system}

Has the system has improved the efficiency of fiscal flat tax adoption in these countries? To answer this question as the comparison base is used in an annual report listing "Paying Taxes" was published by the World Bank in collaboration with the international company PricewaterhouseCooper (PWC) as part of the "Doing Business". The following table presents the ranking by PricewaterhouseCoopers for 5 year progressed fiscal system whose states selected by comparison with other countries. Thick lettering are the years in which the respective state has the PWC climbing in the rankings.

Exhibit 2. Rankings by year of the flat tax reforms

\begin{tabular}{|c|l|c|c|c|c|c|c|}
\hline No. & Countries & Year of Reform & 2008 & 2009 & 2010 & 2011 & 2012 \\
\hline 1 & Serbia & 2003 & 126 & 136 & 138 & 143 & 149 \\
2 & Slovakia & 2004 & 126 & 119 & 122 & 129 & 100 \\
3 & Ukraine & 2004 & 118 & 181 & 181 & 181 & 165 \\
4 & Georgia & 2005 & 110 & 64 & 61 & 39 & 33 \\
5 & Romania & 2005 & 146 & 149 & 151 & 154 & 136 \\
6 & Kyrgyzstan & 2006 & 155 & 156 & 150 & 162 & 168 \\
7 & Kazakhstan & 2007 & 49 & 52 & 39 & 17 & 17 \\
8 & Macedonia & 2007 & $\mathbf{2 7}$ & $\mathbf{2 6}$ & 33 & $\mathbf{2 0}$ & 24 \\
\hline
\end{tabular}




\begin{tabular}{|c|l|c|c|c|c|c|c|}
\hline 9 & Montenegro & 2007 & 139 & 145 & 139 & 114 & 81 \\
10 & Albania & 2007 & 143 & 138 & 149 & 152 & 160 \\
11 & Bulgaria & 2008 & 94 & 95 & 85 & 84 & 91 \\
12 & Czech Republic & 2008 & 118 & 121 & 128 & 117 & 120 \\
13 & Bosnia Herzegovina & 2009 & 154 & 129 & 127 & 118 & 128 \\
14 & Belarus & 2009 & 181 & 183 & 183 & 156 & 129 \\
\hline & Total No. of Countries & & $\underline{181}$ & $\underline{183}$ & $\underline{183}$ & $\underline{183}$ & $\underline{185}$ \\
& reviewed & & &
\end{tabular}

The table above shows that in 2008 only fiscal system of Macedonia and Kazakhstan rank better. Bulgarian fiscal system ranks somewhere in the middle. Other rankings of the countries is under 99 and below. Worse appear Belarus and Bosnia Herceegovina. Bad Ranking of countries according to the effectiveness of the tax system shows that these countries have had to reform the fiscal system. The second fact to note from the table is that, even after the adoption of the flat tax, fiscal systems to order many of these countries remains almost the same.

Seen from the exhibit 2, that, in 2011, the fiscal system of Kazakhstan has become even more efficient, ranking even above. Similarly we can say even for Georgia and Macedonia. Only these three countries have been increasing the efficiency in the fiscal system. In Bulgaria we can say that there are improvements, but still remains somewhere in the middle of the order. Fiscal systems of other countries continue to remain towards the end of the sequence. Extreme cases are Ukraine, Belarus and Kyrgyzstan. This fact shows that the adoption of the flat tax for fiscal system efficiency, did not give result in most of the countries. Looking at the chart performance year after year sort of fiscal systems in 14 countries taken into consideration also revealed other facts that support the idea that the flat tax as a reform to increase the efficiency of the fiscal system is not functioning. Fiscal systems of the former communist countries, from 14, only 3 of them have been increasing the efficiency of the fiscal system. A small part of these countries have had very little variation from year to year, and for most of the countries analyzed, the adoption of a flat tax, does not bring improvement in the rankings.

Year after year shows the speed with which it has operated in the flat tax reform the tax system. There are five states that have applied flat tax reform after 2008. With the exception of Bosnia and Herzegovina, any other case, the period of establishing the order does not coincide with the adoption of the reform period. This discrepancy clearly indicates that not necessarily reforming the fiscal system and the adoption of a flat tax go together. in 2012, data from the table note that only Georgia has earned points in the ranking. Kazakhstan can say that I remained in the same order causes as the previous year, while Macedonia has lost points in 2012, has fallen in the rankings. Please note that the number of countries that are taken into consideration by the World Bank in 2012 has increased, 185. Other countries have decreased even more the efficiency of the tax system. Bulgaria, despite modest improvement in the rankings, remains the last country of the EU with regard to time that I needed a business to pay taxes.

\section{Discussions and Recommendations}

Despite theoretical advantages recommended by its advocates, flat tax, reform remains the best option to reform the fiscal system. Economic studies in developed countries show that the adoption of the flat tax creates significant disparities which, which provide very strong opposition and questioned the possibility for such a reform in a near future. In former communist countries there is little controversy, but the positive results of the adoption of the flat tax, in general, are absent. Reforms have been a necessity for these countries as their fiscal systems have had a significant lack of efficiency. However the selection of flat tax should not have been the best choice. The above facts show that systems of countries that have proven to be hard for the adoption of the flat tax, remained almost at the same level even after the reform. Even in some cases where even further decrease the efficiency of the tax system. It noted that the rankings have had these countries PWC table, compared with other countries that have progressive taxation. The only countries, for which the flat tax might make sense, are states with small populations who are forced to adopt separate flat tax for the specific conditions of their countries.

Critics of the flat tax conclude that the flat tax and fiscal efficiency of the system, not necessarily are to be regarded as two issues go together one with another (Marstin, D. 2005). Also the analysis of the former communist countries that had put new momentum and inconsistencies between the momentum of reform and improvement of the tax system meanwhile, a progressive taxation system can be much more efficient than flat tax system. This conclusion is clear when compared the PWC report, flat Takes countries and those with progressive taxation. There are sites that although progressive taxation and higher taxes, have a fiscal system that countries with efficient flat taxation and lower taxes. The 
desire of the former communist countries at to adopt flat tax seems to have more connection with the low level of tax than the efficiency of the fiscal system. Analysis (Voinea L. 2009) that were made in Romania, show that, a year after the flat tax reform, the poor are poorer and the rich are rich. This analysis confirms the conclusion of Murphy (2006) according to which, a flat tax for the rich so as to avoid their social responsibility by permitting little or no pay and that the state take as little income. I need a full study whether this conclusion applies true in all countries where the flat tax was adopted.

Recommendation for the former communist countries in general, seems to be lifting up from the flat tax and the adoption of a progressive tax system and a system of tax legislative west. Fit the legislature would bring a fiscal system with modern and efficient. Progressive taxation will conduct a fair redistribution of the tax burden between different social groups. State will better function would have more opportunities for social policy and management of the tax system.

\section{References}

Adam, S., Brown, J. (2006). "Options for UK 'flat tax': some simplesimulation", IFS Briefing Note No.72.

Aslund, A. (2007). "How Capitalism Was Built: the transformation of Central and Eastern Europe, Russia and Central Asia". Cambridge, UK: Cambridge University Press.

Baturo, A., J, Gray. (2009). "Flatliners: ideology and rational learning in the adoption of the flat tax", Europe Journal of Political Sience. 48 (1): $130-159$

CIA, (2011). "The world factbook", https://www.cia.gov/library/publications/the-world-factbook/geos/bh.html

CIA, (2010). "The world factbook", https://www.cia.gov/library/publications/the-world-factbook//rankorder/rawdata_2113.txt

Cok, M., Sambt J., Kosak M, Verbic M., Majcen B. (2011) "Distribution of Personal Income Tax Changes in Slovania", Institute for Economic Research - IER, Ljubljana WORKING PAPER No. 57, 2011

Ellis, J. M., (2011). "The Flat Taxin Central Europe: Slovalia and Czesch Republic in Comparative Perspective", Central Europe Juornal of Public Policy Vol. 5 - 1 - June 2011 - pp 24-51

Forbes, S. (2005). "Flat Tax Revolution: Using a Postcard to Abolish the IRS", Washington D.C., Regnery Publishing, Inc.

Fuest, C., A. Piechl, and T. Schaefer (2007). "Is a Flat Tax Feasible in a Grown-up Welfare State?" Institute for the Study of Labor. IZA Discussion Paper 3142.

Grecu, A. (2004). "Flat Tax - The British Case", London: Adam Smith Institute.

Hall, E.R., Rabushka, A., (2007). "The Flat Tax (Hoover Classics)" Hoover Institutio press; 2nd edition

Heineken, K (2006). "A Flat Tax Rate in the Netherland - An Option for the Next Coalition Agrement?"

Jacobs, B., de Mooij, R.A.,Folmer,K., (2007). "Analyzing a flat tax income in the Netherlands", Tinbergen Institute Discussion Paper 2007-029/3

Keen M., Kim Y., Varsano R. (2006). "The Flat Tax(es): Pinciples and Evidence." Intrenational Monetary Fund, IMF Working Papers: $06 / 218$.

Kuismanene, M. (2000). "Labour supply and income tax changes: A simulation study for Finland", Bnak of Finland Discission Paper $5 / 2000$

Larsen, T (2006) "A flat tx in Danmark?"

Martin, D. (2005), "An overview of the flat tax" London: Centre for Policy Studies

Orenstien, M. A., (2011). "Who needs a flat tax?" http://www.project-syndicate.org/commentary/orenstien4/English

Peichl, A. 92008). "Could the World be Flat? Simulating Flat Tax Reform in Western Europe" Phd paper

Rabushka, A.. (2010) "Iceland Abandons the Flat Tax", http://www.flattaxes.blogspot.com/2010/03/iceland-abandons-flat-tax.html

Rabushka, A., (2010). "Flat Tax Countries and Jurisdictions September 2010", http://www.flattaxes.blogspot.com/2010/03/icelandabandons-flat-tax.html

Voinea, L., Mihaescu, F., (2009). "The Impact of the Flat Tax Reform on Inequality-the case of the Romania", Romanian Journal of Economic Forecasting, 2009, volume 12 issue 4, 19-41

Weisbach, D. A., (2000). "Ironing Out the Flat Tax", Stanford Law Review, Vol. 52, No. 3 (Feb.,2000), pp. 599-664

World Bank, PricewaterhouseCooper, (2008) "Paying Taxes 2009, the Global Picture" www.pwc.com/gx/en/paying-taxes/pdf /paying_taxes_2009.pdf

World Bank, PricewaterhouseCooper, (2009) "Paying Taxes 2010, the Global Picture" www.pwc.com/gx/en/paying-taxes/pdf /paying_taxes_2010.pdf

World Bank, PricewaterhouseCooper, (2010) "Paying Taxes 2011, the Global Picture" www.pwc.com/gx/en/paying-taxes/pdf /paying_taxes_2011.pdf

World Bank, PricewaterhouseCooper, (2011) "Paying Taxes 2012, the Global Picture" www.doingbusiness.org/ /media/FPDKM/Doing \%20Business/Documents/Soecial-Reports/Paying_Taxes_2012.pdf

World Bank, PricewaterhouseCooper, (2012) "Paying Taxes 2013, the Global Picture" http://www.doingbusiness.org/ /media IGIAWB/Doing\%20Business/Documents/Special-Reports/Paying-Taxes-2013.pdf 